\title{
ПІДВИЩЕННЯ КВАЛІФІКАЦІї ПЕРСОНАЛУ В СУЧАСНИХ УМОВАХ ТА РОЗВИТОК ТЕНДЕНЦІЙ КОРПОРАТИВНИХ ОСВІТНІХ ПРОЦЕСІВ
}

\section{IMPROVEMENT OF STAFF IN MODERN CONDITIONS AND DEVELOPMENT OF TRENDS IN CORPORATE EDUCATIONAL PROCESSES}

\author{
Панкратова Олена Миколаївна \\ кандидат економічних наук, доцент, \\ Харківський національний університет імені В.Н. Каразіна \\ ORCID: https://orcid.org/0000-0002-7250-4561 \\ Pankratova Olena \\ V.N. Karazin Kharkiv National University
}

\begin{abstract}
У цій статті розглядається необхідність та доцільність впровадження новацій в освітній корпоративний процес підприємств під час підвищення кваліфікації персоналу. Визначено, що планування розвитку персоналу, яке передбачає проведення інтегрування систем управління ефективністю є важливою складовою управління ефективністю. Наведені причини чому наймані працівники недостатньо зацікавлені вкладати особисті кошти у свою підготовку, перепідготовку чи підвищення кваліфікації через відсутність для цього достатніх матеріальних і моральних стимулів, сприймаючи навчання як марнування часу. Визначений зміст корпоративного навчання $з$ допомогою використання навчальних курсів з масовою інтерактивною участю із застосуванням технологій електронного навчання і відкритим доступом через Інтернет, використання ідей краудсорсингу, що має за мету залучення до вирішення тих чи інших проблем інноваційної виробничої діяльності широкого кола осіб для використання їх творчих здібностей, знань і досвіду по типу субпідрядної роботи на добровільних засадах із застосуванням інформаційно-комунікаційних технологій.
\end{abstract}

ключові слова: персонал, розвиток персоналу, професійна підготовка, стимулювання працівників, краудсорсинг.

В этой статье рассматривается необходимость и целесообразность внедрения новаций в образовательный корпоративный процесс предприятий при повышении квалисикации персонала. Определено, что планирование развития персонала, которое предусматривает проведение интеграции систем управления эффрективностью является важной составляющей управления эффективностью. Приведенные причины почему наемные работники недостаточно заинтересованы вкладывать личные средства в свою подготовку, переподготовку или повышение квалификации за отсутствия для этого достаточных материальных и моральных стимулов, воспринимая обучение как пустая трата времени. Определенный смысл корпоративного обучения за счет использования учебных курсов по массовой интерактивной участием с применением технологий электронного обучения и открытым доступом через Интернет, использование идей краудсорсинга, что имеет целью привлечение к решению тех или иных проблем инновационной производственной деятельности широкого круга лиц для использования их творческих способностей, знаний и опыта по типу субподрядной работы на добровольных началах с применением иноромационно-коммуникационных технологий.

Ключевые слова: персонал, развитие персонала, профессиональная подготовка, стимулирование работников, краудсорсинг.

The relevance of the chosen topic lies in the fact that with the help of new training methods, techniques and technologies, the personnel management system is actively functioning. As a result, new training methods, methods of professional training of employees at the enterprise are gaining popularity. This article discusses the necessity to introduce a new educational corporate process of enterprises while developing staff. Determined that personnel development planning. It has been determined that personnel development planning, which provides for the integration of efficiency management modules, is an important component of performance management. The following are the reasons why hired workers are not sufficiently interested in investing personal resources in their training, retraining 
or advanced training in the absence of reasonable material and moral incentives for this, perceiving training as a waste of time. The content of corporate training has been identified through the use of training courses with massive interactive participation using e-learning technologies and open access via the Internet, the use of crowdsourcing ideas, which aims to involve a wide range of people in solving various problems of innovative production activities to use their creative abilities, knowledge and experience similar to the subcontracting work on a voluntary basis using information and communication technologies. Taking this into account, the purpose of the study is to consider the theoretical foundations and the introduction of corporate training tools to improve the personnel development system and educational processes at the enterprise. To achieve the goal, the following task was formulated and solved: to propose measures to improve the system of advanced training and personnel development. In the course of the research, the methods of logical analysis, comparison, classification, systematization, graphical presentation of materials, and theoretical generalization were used. The practical significance lies in the fact that the newest methods and forms of personnel development are replacing the traditional format of personnel training.

Keywords: staff, staff development, professional training, incentives for employees, crowdsourcing.

Постановка проблеми. 3 розвитком науки, техніки та технології, активно фрункціонує система менеджменту персоналу, в межах якої набувають популярності новітні методи, техніки, способи профресійного навчання працівників на підприємстві.

В умовах сьогодення на українському ринку праці підвищуються вимоги до персоналу, який займається розробкою, впровадженням, обслуговуванням, моніторингом та управлінням господарськими процесами на підприємстві, адже рівень квалісрікації працівників $€$ основою для досягнення ефективної діяльності.

Сучасні мобільні технології стають нормою для ведення бізнесу, необхідною умовою для його розвитку та інтеграції з іншими учасниками ринку - як клієнтами, так і постачальниками послуг. При цьому традиційний фрормат підвищення кваліфрікації у вигляді проведення аудиторних занять відходить у минуле, натомість якому запроваджуються у практику HR-менеджменту новітні реалії, які поєднані із сучасними Інтернет-технологіями, вимагають значного рівня розвитку особистісних компетенцій, що корелюють із загальним рівнем інтелекту, креативності, творчості, комунікабельності, винахідливості тощо.

Аналіз останніх досліджень і публікацій. Питання професійного навчання, підвищення кваліфрікації та розвитку персоналу взагалі висвітлені у роботах багатьох вітчизняних вчених, серед яких чималий внесок у розгляд цієї проблематики здійснили такі з них, як Верхоглядова Н.І., Залознова Ю.С., Назарова Г.В., Петрова Т.В., Савченко В.А., Ястремська О.М. Дослідження цих вчених мають фрундаментальний характер, що охоплюють питання методів проведення та фрінансування навчання, впливу сорормованих компетентностей на результативність діяльності підприємства тощо.

Виділення невирішених раніше частин загальної проблеми. В працях вищеперерахованих вчених не висвітлені детально питання запровадження новітніх тенденції у проведенні внутрішньокорпоративного навчання.

Формулювання цілей статті (постановка завдання). Метою дослідження виступає розгляд теоретичних положень та запровадження засобів корпоративного навчання щодо удосконалення системи підвищення кваліфікації персоналу та освітні процеси на підприємстві. Для досягнення мети сорормульоване та вирішене наступне завдання: розгляд основних тенденцій корпоративних освітніх процесів та підвищення кваліфікації персоналу за допомогою використання новітніх тенденцій.

Виклад основного матеріалу дослідження. Розглядають необхідність та доцільність впровадження новацій в освітній корпоративний процес підприємств під час підвищення кваліфікації персоналу колектив авторів під керівництвом Назарової Г.В. [4].

Чимало підприємств намагаються створити сукупність сильної команди з числа талановитих молодих працівників, користуючись предикативною аналітикою, отже, HR-системи повинні включати в аналіз не тільки результативні показники діяльності працівників, але навички, здібності, особистісні риси. При цьому простий розподіл на талановитих співробітників та тих, хто вимагає додаткового розвитку вже $\epsilon$ неесективним, адже означену інорормацію необхідно доводити рівноправно до працівників, давати їм зворотний зв'язок.

Важливою складовою управління ефективністю $є$ планування розвитку персоналу, що передбачає проведення інтегрування систем управління ефрективності та навчання своїх систем для того, щоб розуміти який досвід та навички можуть бути потрібні в майбутньому.

У зв'язку із зростанням мобільності талантів, їх підбір стає критичною частиною управління талантами. Коли працівник приєднується до підприємства, можуть змінюватися ролі й вимоги до посади, працівник може бути висунутий на заміщення більш високої посади. Таким чином, 
підприємство повинне бути готовим до цих змін і до того, що потенційно відповідні навички повинні бути присутніми у працівника або можуть бути розвинені. Ейчари починають розуміти, що «підбір» $\mathrm{i}$ «мобільний менеджмент» мають схожі завдання і найближчим часом необхідно очікувати доробок в нових системах з урахуванням цього положення.

Зміст корпоративного навчання $€$ фрундаментальними стратегічними цілями HR-системи. Сьогодні кожне підприємство має потребу в перенавчанні технічного персоналу (причому, цей процес стає перманентним), у навчанні нових співробітників, навчанні працівників тому, як робити свою роботу краще. 3 огляду на це, зміст корпоративного навчання повинен корелювати із: по-перше, новаціями в техніко-технологічному напрямі підприємства; по-друге, тенденціями ринку, вимогами споживачів, досягненнями фундаментальної науки; по-третє, набором вже наявних компетентностей особистісного та професійного характеру. При цьому така відома технологія HR-менеджменту, як LMS (від англ. the learning management system - система навчального менеджменту) характеризується зсувом від ії першопочаткової задумки як «системи адміністрування навчального процесу» до як «платфрорми залучення в процес навчання». Нові LMS інтегрують процес навчання з процесами управління талантами і управління ефективністю, включають інтегрований контент та експертизу менеджменту. Вони активно використовують можливості YouTube 3 широким спектром інструментів і джерел контенту. Так, наприклад, нова технологія «Тін-Кан» дозволяє відстежувати всі активності учнів, включаючи навіть кліки по посиланнях на сайти $[2 ; 6]$.

Розвиток «інтелектуального навчання» як ключовий фрактор успіху діяльності підприємства, що полягає в тому, що під час самостійного електронного навчання на екрані ПК з'являються навчальні завдання на основі реальнихпроцесів, що безпосередньопов'язані з тими завданнями, що в певний момент часу виконує працівник. Такі операції можливі, якщо систему навчального менеджменту вбудовано до CRM-системи управління (від англ. customer relationship management - управління відносинами 3 клієнтами), що й дозволяє ув'язувати реальні виробничі операції з навчальним контентом окремої групи працівників.

Активний розвиток МООС (від англ. massive open online courses - масові відкриті онлайнкурси) - навчальні курси 3 масовою інтерактивною участю із застосуванням технологій електронного навчання і відкритим доступом через Інтернет. В якості доповнень до традиційних матеріалів навчального курсу, таким як відео, читання і домашні завдання, МООС дають можливість використовувати інтерактивні форуми користувачів, що допомагають створювати і підтримувати спільноти студентів, викладачів і асистентів. МООС активно почали розвиватися на початку 2010-х років й дали можливість інтерактивного спілкування студентів і викладачів, а також складання іспитів у режимі онлайн. Подібні сайти розраховані на слухачів різних рівнів підготовки як на новачків, так і на досвідчених фрахівців. Найпопулярніші масові онлайн-курси збирають сотні тисяч студентів. При цьому у слухачів існує можливість отримати сертифрікат з опанування будь-якого курсу найпрестижніших університетів світу за невелику платню. МOOC набирають популярність як вид підвищення кваліфрікації через відносно невелику ціну та швидкий термін проходження курсу [8].

Використання ідей краудсорсингу (залучення до вирішення тих чи інших проблем інноваційної виробничої діяльності широкого кола осіб для використання їх творчих здібностей, знань і досвіду по типу субпідрядної роботи на добровільних засадах із застосуванням інформаційно-комунікаційних технологій) або соціальних систем при розробці навчальних курсів, який розглядається як передача певних фуннцій невизначеному колу осіб, вирішення суспільно значущих фрункцій силами волонтерів, дії яких координуються з єдиного центру. Ця технологія була створена у розрахунку на бажання споживачів безкоштовно або за незначну плату поділитися своїми ідеями виключно 3 інтересу побачити їх втіленими в життя. Практика HR-менеджменту направлена на те, щоб простим голосуванням у внутрішньо корпоративній системі отримати зворотній зв'язок або коментар на будь-яку нову програму, організаційну зміну, нову ідею тощо. Багато провайдерів пропонують інструменти визнання в режимі реального часу, що відразу показує «престижність» певних співробітників і «винагороджує» їх. Цей інструмент надає критичний вплив на залученість працівників, яка стає важливою темою управління керівництва підприємства [7].

Інтеграція інтернет-технологій в усі сорери управління підприємством, постійне оновлення програмних продуктів, що пропонуються провайдерами, їх тісний зв'язок з аналітикою, дослідженнями та моніторингом ринку, не залишають осторонь й HR-процеси, які, в свою чергу, стають надійним інструментом роз- 
робки ефрективної кадрової політики підприємства. При цьому HR-процеси реалізуються не заради виконання певного фрункціоналу, а для демонстрації створення доданої вартості бізнесу. В цьому контексті розробляються й запроваджуються у практику новації у проведенні внутрішньо корпоративного навчання. Не всі 3 перелічених тенденцій активно використовуються на вітчизняних підприємствах через низку причин, серед яких: низький рівень автоматизації управлінських та виконавських процесів, високий рівень цін на програмні продукти та послуги провайдерів з їх обслуговування, мовні бар'єри персоналу тощо. Проте відкриття кордону європейського ринку для вітчизняних виробників створює широкі можливості для опанування новітніх технологій внутрішньо корпоративного навчання задля підвищення рівня конкурентоспроможності підприємств.

Наймані працівники іноді також недостатньо зацікавлені вкладати особисті кошти у свою підготовку, перепідготовку чи підвищення кваліфрікації через відсутність для цього достатніх матеріальних і моральних стимулів, сприймаючи навчання як марнування часу. Наведені причини на рисунку 1.

Механізм стимулювання працівників підприємства щодо посилення їхньої зацікавленості у безперервному вдосконаленні своїх знань і вмінь має ґрунтуватися на позитивному ставленні керівників до навчання своїх підлеглих, системі обліку результатів кваліфікаційної атестації та сертифрікації працівників у межах планування їх трудової кар'єри, у переході від мотивації праці до мотивації професіоналізму.

Політика у сфрері навчання персоналу має спрямовуватися на забезпечення прав працівників на здобуття вищої та професійнотехнічної освіти відповідно до їхніх інтересів, покликань, здібностей і задоволення потреб усіх сорер економічної діяльності у кваліфрікованих і конкурентоспроможних на ринку праці працівників. У зазначеному напрямі здійснено ряд позитивних кроків.

Заходи щодо стимулювання розвитку найманих працівників мають відображатися в

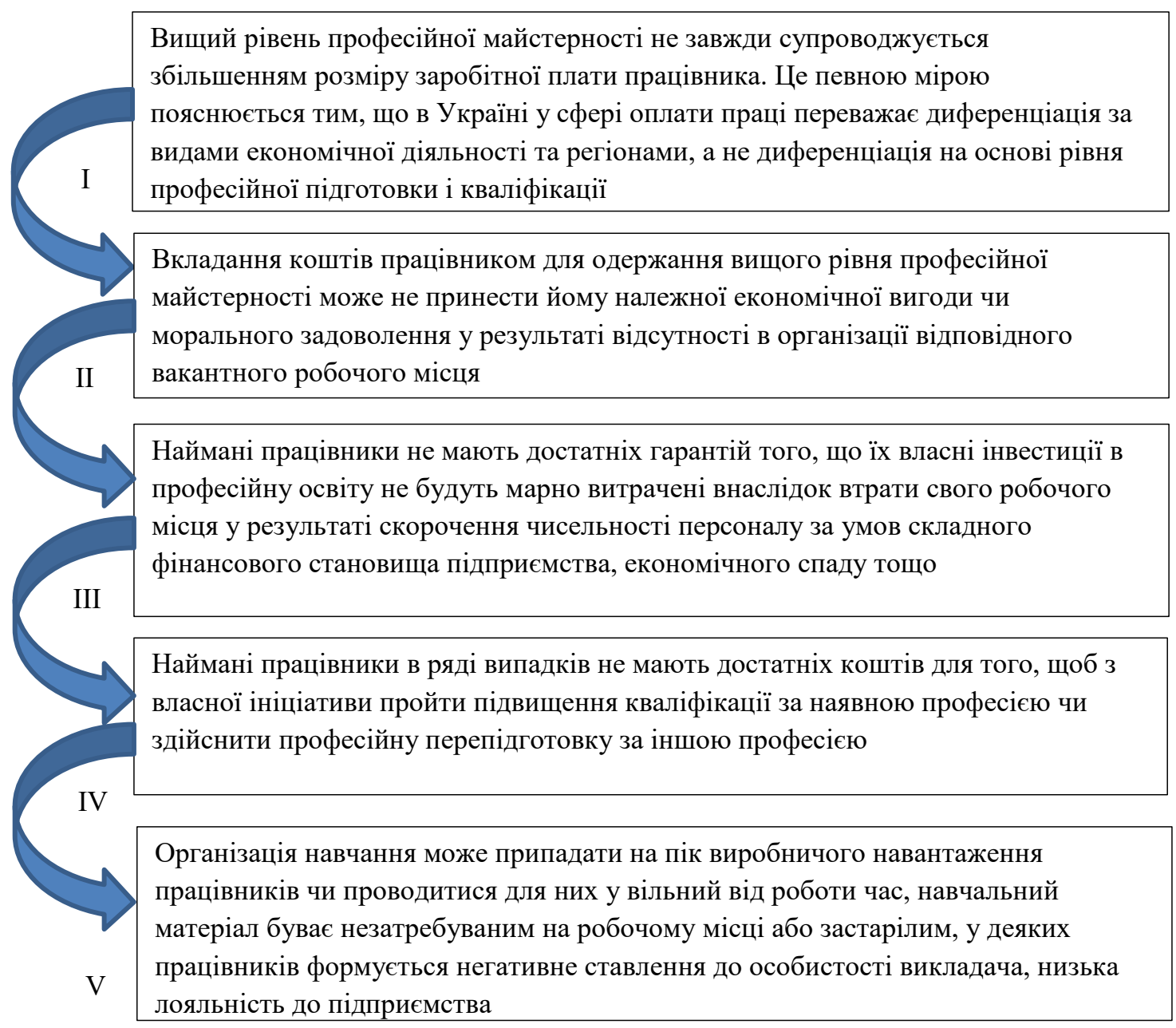

Рис. 1. Основні причини чому наймані працівники недостатньо зацікавлені вкладати особисті кошти у свою підготовку, перепідготовку чи підвищення кваліфікації [5; 6] 
соціальному плануванні підприємства. У плані надання освіти за рахунок підприємства передбачається, що компанія оплачує програми навчання, що випливають 3 виробничих планів. Підприємство може надавати працівникові в порядку заохочення й допомоги в розвитку кар'єри пільги у вигляді оплати програм, запроваджених ВНЗ (вивчення іноземної мови, підприємництва й менеджменту), зокрема у повному обсязі в разі дотримання низки умов [2].

3 метою розширення профрілю кваліфрікації працівників та виявлення їхніх можливостей широко практикується ротація персоналу. Періодична зміна робочих місць упродовж трудової діяльності співробітника (зазвичай 3-4 рази) вважається найкращим способом підвищення кваліфрікації персоналу. Наприклад, у японській корпорації «Као» протягом десятиріччя весь персонал опановує щонайменше три профресії. Процес перепідготовки, що має безперервний характер, тісно пов'язаний 3 реалізацією ідеї збагачення праці, розширення відповідальності, делегування права прийняття рішень.

Перспективним напрямом стимулювання професійного розвитку найманих працівників $€$ створення індивідуальних навчальних рахунків, у перерахуванні коштів на які беруть участь як держава та роботодавець, так і сам працівник. Отже, має місце спільна зацікавленість і відповідальність за досягнуті результати, що $є$ більш справедливим, ніж коли витрат зазнає одна сторона, а переваги отримують усі [3].

Індивідуальні навчальні рахунки сприяють підвищенню відповідальності працівника за свій розвиток, $€$ більш ефективними порівняно $з$ урядовими заходами щодо стимулю- вання навчання персоналу на виробництві, спрямованими на роботодавців. Право працівників на індивідуальні навчальні рахунки має бути відображеним у Законі України «Про профресійний розвиток працівників» під час внесення змін до нього.

Висновки. Таким чином, визначено, що підвищення кваліфрікації для персоналу відрізняється від підвищення кваліфрікації робітників фрормою, методами навчання, тривалістю тощо. Виявлено новітні тенденції у проведенні внутрішньо корпоративного навчання, а також напрями стимулювання розвитку працівників на підприємстві. Доведено, що зміст корпоративного навчання $€$ фрундаментальними стратегічними цілями HR-системи. На сьогодні кожне підприємство має потребу в перенавчанні персоналу, у навчанні нових співробітників, навчанні працівників тому, як робити свою роботу краще. Виявлені причини чому наймані працівники іноді також недостатньо зацікавлені вкладати особисті кошти у свою підготовку, перепідготовку чи підвищення кваліфікації через відсутність для цього достатніх матеріальних і моральних стимулів, сприймаючи навчання як марнування часу. Запропоновані були заходи щодо стимулювання розвитку найманих працівників, що мають відображатися в соціальному плануванні підприємства. У плані надання освіти за рахунок підприємства передбачається, що компанія оплачує програми навчання, що випливають 3 виробничих планів. Політика у сорері навчання персоналу має спрямовуватися на забезпечення прав працівників на здобуття вищої та просресійно-технічної освіти відповідно до їхніх інтересів, покликань, здібностей і задоволення потреб усіх сорер економічної діяльності.

\section{СПИСОК ВИКОРИСТАНИХ ДЖЕРЕЛ:}

1. Бабич Д.В., Свідерський В.П., Четверікова А.В. Сучасні тенденції корпоративних освітніх процесів та професійного навчання персоналу на підприємстві. Економіка і суспільство, 2018, 16(2018), 241-246. URL https://economyandsociety.in.ua/journals/16_ukr/37.pdf

2. Ільїч Л.М. Державне регулювання профресійної підготовки кадрів: світовий досвід. Ринок праці та освіта: пошук взаємодії : зб. наук. ст. Київ : Таксон, 2007. 293 с.

3. Левченко О. Сучасна безперервна професійна освіта та підготовка кадрів в Україні: основні проблеми та напрями транссормації в контексті міжнародного досвіду, Україна: аспекти праці, 2016, 1, 30-35.

4. Назарова Г.В. Управління розвитком діяльності промислових підприємств : монографія. Харків : XHEУ, 2010.

5. Савченко В.А. Організаційно-економічні аспекти професійного навчання на виробництві : монограсрія.

Київ : Видавництво Інституту професійно-технічної освіти НАПН України, 2012.

6. Савченко В.А. Управління розвитком персоналу. Київ : КНЕУ, 2017.

7. Кацуба Н. Онлайн-образование: как это возможно в Украине. URL: http://lampa.today/biznes/onlajnobrazovanie-kak-eto-vozmozhno-v-ukraine/

8. MOOC news\&reviews. URL: http://moocnewsandreviews.com/what-do-we-know-about-mooc-students-so-far/ 


\section{REFERENCES:}

1. Babych D.V., Sviderskyi V.P., Chetverikova A.V. (2018) Suchasni tendentsii korporatyvnykh osvitnikh protsesiv ta profesiinoho navchannia personalu na pidpryiemstvi [Current trends in corporate educational processes and professional training of staff at the enterprise]. Ekonomika $i$ suspilstvo - Economy and society, 16, 241-246. Retrieved from: https://economyandsociety.in.ua/journals/16_ukr/37.pdf (in Ukrainian)

2. Ilich L.M. (2007) Derzhavne rehuliuvannia profesiinoi pidhotovky kadriv: svitovyi dosvid [State regulation of professional training: world experience]. Rynok pratsi ta osvita: poshuk vzaiemodii: zb. nauk. st. - Labor market and education: the search for interaction: a collection of scientific articles. Kyiv: Takson, 293 p. (in Ukrainian)

3. Levchenko O. (2016) Suchasna bezperervna profesiina osvita ta pidhotovka kadriv v Ukraini: osnovni problemy ta napriamy transformatsii v konteksti mizhnarodnoho dosvidu [Modern continuing vocational education and training in Ukraine: main problems and directions of transformation in the context of international experience]. Ukraina: aspekty pratsi - Ukraine: aspects of work, 1, 30-35. (in Ukrainian)

4. Nazarova H.V. (2010) Upravlinnia rozvytkom diialnosti promyslovykh pidpryiemstv [Management of development of activity of industrial enterprises]. Kharkiv: KhNEU. (in Ukrainian)

5. Savchenko V.A. (2012) Orhanizatsiino-ekonomichni aspekty profesiinoho navchannia na vyrobnytstvi [Organizational and economic aspects of vocational training in the workplace]. Kyiv: Vydavnytstvo Instytutu profesiino-tekhnichnoi osvity NAPN Ukrainy. (in Ukrainian)

6. Savchenko V. A. (2017) Upravlinnia rozvytkom personal [Personnel development management]. Kyiv: KNEU. (in Ukrainian)

7. Katsuba N. Onlain-obrazovanye: kak eto vozmozhno v Ukrayne [Online education: how is it possible in Ukraine]. Retrieved from: http://lampa.today/biznes/onlajn-obrazovanie-kak-eto-vozmozhno-v-ukraine/ (in Ukrainian)

8. MOOC news\&reviews. Retrieved from: http://moocnewsandreviews.com/what-do-we-know-about-mooc-students-so-farl 